Section Editor

Mitchell S.V. Elkind,

MD, MS

Wendy K.M. Liew, $\mathrm{MBChB}, \mathrm{MRCPCH}$

Basil T. Darras, MD

Correspondence to

Dr. Liew:

wendy.liew@childrens.harvard.edu

Teaching NeuroImages:

\title{
Characteristic phenotype of Ullrich congenital muscular dystrophy
}

\section{Figure Classic signs of Ullrich congenital muscular dystrophy}
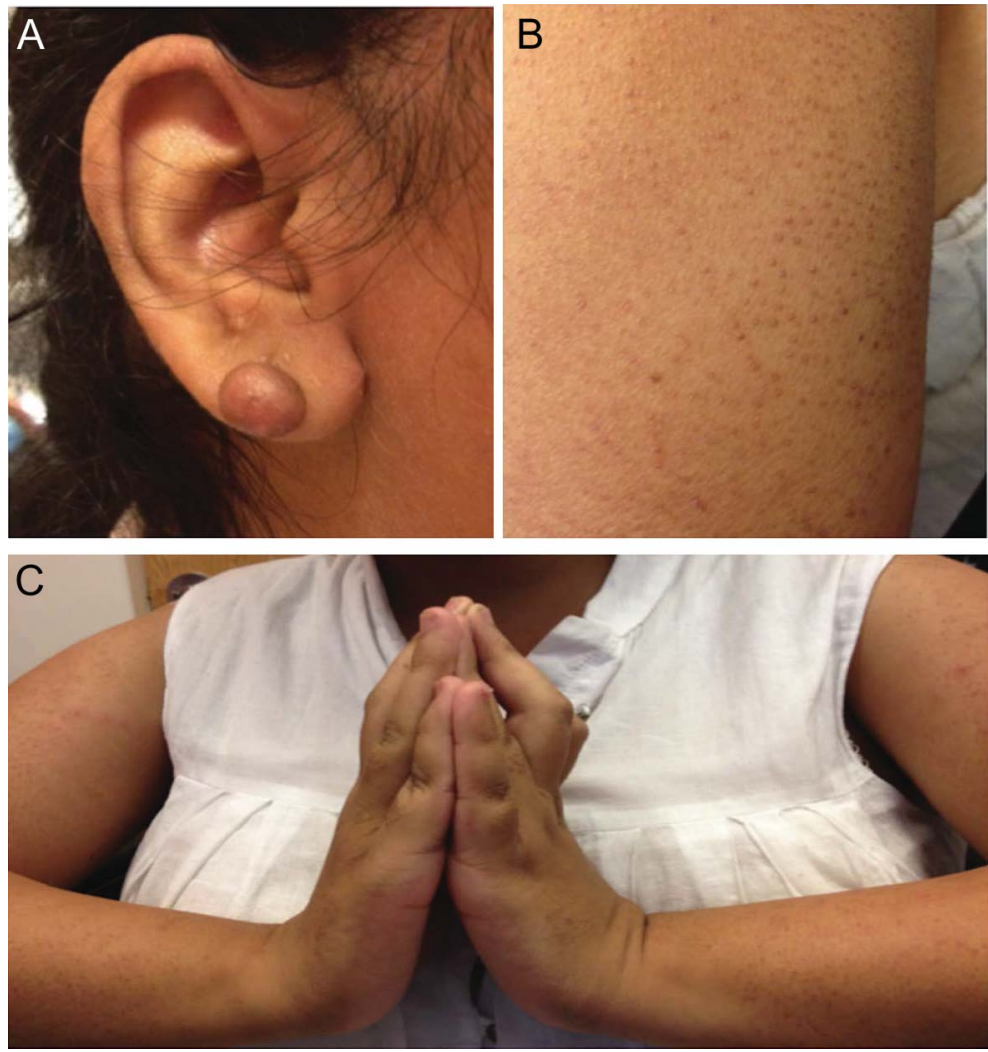

A 21-year-old woman with progressive limb-girdle weakness, elbow contractures, and hyperlaxity of distal joints also exhibited the following: (A) keloid formation after ear piercing; (B) follicular hyperkeratosis of the arm; and (C) Bethlem sign-flexion contractures of the fingers on wrist extension.

A 21-year-old woman presented with clinically classic signs of Ullrich congenital muscular dystrophy ${ }^{1}$ (figure). Genetic testing of collagen VI genes revealed a homozygous mutation c. $2329 \mathrm{~T}>\mathrm{C}$, p.Cys777Arg in the COL6A2 gene, consistent with the clinical diagnosis.

Collagen type VI-related disorders represent a spectrum of overlapping phenotypes: Bethlem myopathy at the milder end, and Ullrich congenital muscular dystrophy at the severe end. ${ }^{2}$ Its clinical features may resemble Emery-Dreifuss muscular dystrophy, but absence of cardiac abnormalities is helpful in distinguishing these 2 disorders. Recognition of typical clinical features can aid in the diagnosis and help to shorten a potentially lengthy diagnostic workup.

\section{AUTHOR CONTRIBUTIONS}

Wendy Liew: drafting and revision of manuscript. Basil Darras: interpretation of data and manuscript revision.

\section{STUDY FUNDING}

No targeted funding reported.
Download teaching slides: www.neurology.org 
DISCLOSURE

W. Liew reports no disclosures. B. Darras is a consultant for ISIS Pharmaceuticals and Quest Diagnostics, received funding for travel from Athena Diagnostics, an honorarium for Virtual Grand Rounds, received research support from PTC Therapeutics, the Spinal Muscular Atrophy Foundation, the Muscular Dystrophy Association, the Slaney Family Fund for SMA, and the NIH/NIAMS. Go to Neurology.org for full disclosures.

\section{REFERENCES}

1. Bonnemann CG. The collagen VI-related myopathies Ullrich congenital muscular dystrophy and Bethlem myopathy. Handb Clin Neurol 2011;101: 81-96.

2. Lampe AK, Bushby KM. Collagen VI related muscle disorders. J Med Genet 2005;42:673-685. 


\section{Neurology}

\section{Teaching NeuroImages: Characteristic phenotype of Ullrich congenital muscular dystrophy}

Wendy K.M. Liew and Basil T. Darras

Neurology 2013;81;e44-e45

DOI 10.1212/WNL.0b013e3182a08d13

This information is current as of August 12, 2013

\section{Updated Information \& Services \\ Supplementary Material \\ References \\ Subspecialty Collections}

Permissions \& Licensing

Reprints including high resolution figures, can be found at: http://n.neurology.org/content/81/7/e44.full

Supplementary material can be found at: http://n.neurology.org/content/suppl/2013/08/11/81.7.e44.DC1

This article cites 2 articles, 1 of which you can access for free at: http://n.neurology.org/content/81/7/e44.full\#ref-list-1

This article, along with others on similar topics, appears in the following collection(s):

All Neuromuscular Disease

http://n.neurology.org/cgi/collection/all_neuromuscular_disease All Pediatric

http://n.neurology.org/cgi/collection/all_pediatric

Clinical neurology examination

http://n.neurology.org/cgi/collection/clinical_neurology_examination Muscle disease

http://n.neurology.org/cgi/collection/muscle_disease

Information about reproducing this article in parts (figures,tables) or in its entirety can be found online at:

http://www.neurology.org/about/about_the_journal\#permissions

Information about ordering reprints can be found online:

http://n.neurology.org/subscribers/advertise

Neurology ${ }^{\circledR}$ is the official journal of the American Academy of Neurology. Published continuously since 1951, it is now a weekly with 48 issues per year. Copyright () 2013 American Academy of Neurology. All rights reserved. Print ISSN: 0028-3878. Online ISSN: 1526-632X.

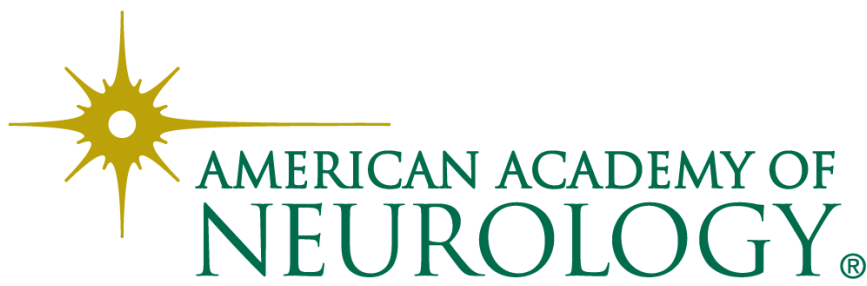

